\title{
Containment of COVID-19: International experience and management strategies
}

\author{
Andrejs Vilks ${ }^{1}$ and Aldona Kipane ${ }^{1}$ \\ ${ }^{1}$ Riga Stradins University, Faculty of Law, Riga, Latvia
}

\begin{abstract}
The aim of the article is to study the international experience in the field of containment of COVID-19 and strategies for overcoming its negative effects. Descriptive, analytical, synthetic and modelling methods are used in the study. The authors analyze the international and national legal framework for the containment of COVID-19, as well as the results of particular studies in this field. The epidemiological, social, economic, legal and other effects of COVID-19 on modern society are comprehensive and possibly long lasting. The pandemic has affected all regions of the world. However, different countries and groups of countries are developing and implementing different COVID-19 management strategies and models to reduce negative impacts of it.
\end{abstract}

Key words - COVID-19, containment strategies, pandemic, society.

\section{Introduction}

When analyzing the COVID-19 containment strategies, it would be methodologically appropriate to identify the nature and content of the concepts to be used. It should be acknowledged that the term 'strategy' is largely derived from the military. However, in the context of the common COVID-19 containment policy and the process of implementing it, which may be reminiscent of the pandemic invasion in certain areas and regions, an understanding of strategies can play an important role. The term "strategy" is etymologically derived from the Greek "strategia" and the French "strategie", which means the development of plans and the setting of operating principles aiming at achieving an important, far-reaching goal [1]. In the development of strategies, including the COVID-19 containment strategies, the necessary material, financial and human resources that enable the optimal outcome to be achieved in the shortest possible time are fully identified, i.e. the spread of COVID-19 is minimized and its negative effects are eliminated. Potential risks (threats) that may hinder the achievement of the results planned, as well as neutralization of potential risks, are analyzed in strategic documents [2]. The analysis of COVID-19 containment strategies is complicated by circumstances of a transnational nature that can be impacted nominally within the national framework.

Several aspects can be identified in the strategic context of the COVID-19 containment. Firstly, it is the initial national and international response and strategic framework by identifying the spread of COVID-19 and identifying its outbreaks. Second aspect is strategically important actions (political, epidemiological, legal, etc.) in preventing the rapid spread of the pandemic, reducing the increase in mortality. Third aspect - strategic guidelines for preventing the negative effects of the pandemic, and the fourth is strategies for the recovery of 
the social and economic situation. The proposed strategic models of the COVID-19 containment relate to the process of pandemic spread, its evolution. Pandemic control strategies can be differentiated according to their coverage: (a) global (developed by the UN, the World Health Organization); (b) regional (e.g. European, developed by the European Commission, European Medicines Agency); (c) national (developed by individual countries); (d) local (strategies are developed within the framework of individual cities, counties, lands). There is no doubt that these strategies, their types and elements are interlinked and successive. However, measures to establish, spread and limit the pandemic and to manage its negative effects include specific tasks and activities.

\section{Results and discussion}

In seeking to overcome the crisis caused by the coronavirus pandemic and by mitigating its negative effects, countries have developed and used different strategies and approaches to balance restrictive measures and the exercise of individual rights and freedoms. It should be acknowledged that looking at international experience in limiting COVID-19 several constructive and practical types of strategies can be identified. The WHO has developed a strategy to combat COVID-19 [3], which was updated on April 14 2020. The strategy recognizes that "The coronavirus (COVID-19) pandemic is exacting a huge toll on individuals, families, communities, and societies across the world. Daily lives have been profoundly changed, economies have fallen into recession, and many of the traditional social, economic, and public health safety nets that many people rely on in times of hardship have been put under unprecedented strain." The WHO states that the most important task for all countries is to control the pandemic by slowing the spread of the virus and reducing the number of deaths associated with COVID-19. The global strategic objectives are outlined in the strategy:

- Mobilize all sectors and communities to fight the pandemic.

- Control sporadic cases and clusters and prevent community transmission by quickly finding and isolating infected people.

- Prevent the spread of the virus by applying physical distance and restricting domestic and cross-border travel.

- Reduce mortality by providing medical care.

- Develop safe and effective vaccines and therapeutics.

The WHO points out that each national strategy has a crucial part to play in achieving global objectives. It must at a minimum, set a basis for coordination of the national and sub-national response, for mobilization of affected communities, provision of necessary medical and sanitary measures to stop the spread of the virus, for preparation of the health system to reduce mortality, medical staff safety and protection, and for preparation of a contingency plan to ensure vital functions.

Boston Consulting Group (BCG) has an interesting approach, which identifies several types of strategies for controlling the coronavirus and restarting the economy. BCG distinguishes the following types: (a) crush and contain; (b) flatten and fight; (c) sustain and support [4].

The Crush-and-contain strategy is characterized by the rapid imposition of restrictions, mass tests, treatment, quarantine and isolation of infected persons, and contact tracking. In addition, strict border controls are ensured. In such circumstances, economic activities 
(tourism, entertainment and catering, etc.) are restricted and closed in certain areas. A small number of countries have taken swift action to limit the spread of the coronavirus, and in some cases have managed to stop the transmission of the virus almost completely. However, it must be acknowledged that many countries do not have the potential and resources to maintain long-term and strict quarantine restrictions, carry out mass testing, and control individuals in quarantine and isolation. The Crush-and-contain strategy has been successfully implemented in Taiwan, China, New Zealand and South Korea.

The COVID-19 containment strategy of Taiwan is interesting and remarkable [5]. Taiwan already had severe experience with the outbreak of global SARS (Severe acute respiratory syndrome) in 2003. Taiwan's government was criticized for belated and inadequate response to public health protection and failure to take comprehensive measures, including restrictions on liberties and freedoms of individuals. In 2011, the Constitutional Court examined applications for unjustified restrictions on the rights of individuals during the epidemic in 2003. The Court found that compulsory physical checks, temporary detention or quarantine, or other similar conditions were not contrary to the principle of legal proportionality. The Constitutional Court warned the government that, despite the need to prevent and combat serious infectious diseases, the Communicable Disease Control Act (CDC) should set a mandatory quarantine period and lay down specific rules. It is important that for quarantined persons it advised to quickly identify and implement remedies and to provide for an appropriate compensation system.

On January 20, 2020, the Taiwan Centres for Disease Control (CECC) was established [6], external borders were closed; mass testing of the population, isolation and control of infected persons was organized. The Special Act for Prevention, Relief and Revitalization Measures for Severe Pneumonia with Novel Pathogens Special Act or COVID-19 was adopted on February 25, 2020. Social distancing, wearing of masks and other epidemiological safety measures were supported. Persons who were subject to isolation or quarantine or who had to take care of those isolated or quarantined were able to receive daily compensation of at least 1000 Taiwan dollars (EUR 30) for 14 days. Population vaccination took place. In Taiwan, the COVID-19 pandemic was significantly controlled, but companies, enterprises and activities were not necessarily closed or banned. However, taking into consideration the situation, many companies and enterprises were willing to voluntarily restrict activities and events or close down. It should be acknowledged that a number of sectors have been hit hard, including tourism, catering and transport companies. To compensate for the losses the government imposed subsidies, compensation, revitalization funds for industries that were in dire need of it. The additional funding amounts are 60 billion Taiwan dollars (EUR 1.8 billion). Taiwan's progress in the fight against the new coronavirus has demonstrated its ability to overcome the public health crisis quickly within a transparent, democratic and legal framework. Taiwan's healthcare system continues to work with civil society to identify the best solutions for effective public health. Due to these and other measures only 12 deaths, caused by COVID-19, were recorded in Taiwan by May 1, 2021.

The flatten and fight strategy is characterized by the fact that countries are seeking to maintain their economic activities, did not overload the healthcare system with population mass testing, and quarantine measures are mostly implemented at regional and local levels. Faced with a sharp increase in the number of coronavirus cases countries with appropriate strategies have introduced restrictions on social distancing and quarantine to avoid huge pressures on healthcare systems. Most countries in Europe, South and North America have failed to contain the initial coronavirus outbreak due to high population density or the delayed and inadequate response to the pandemic.

Singapore's pandemic containment model is linked to the fact that living with COVID-19 also means that the country does not completely close its borders. Prime Minister Lee has 
acknowledged that the country needs food, essential supplies, workers, business and other travellers [7]. One must stay connected to the world, with effective safeguards and border restrictions to keep people of Singapore safe. As long as population is mostly vaccinated, there are possibilities to trace, isolate and treat those, who are infected; there are possibilities to prevent a severe and disastrous outbreak. In this new situation, when new coronavirus strains appear, the countries, which are united and disciplined, and introduce sensible safety measures, will be able to reopen their economies and to renew international connections. Introducing a new plan to limit the spread of COVID-19 in Singapore they try to live with the new pandemic, just like the flu. The "new normal" strategy will be based on four cornerstones: vaccination, testing, treatment and social responsibility [8]. It is assumed that COVID-19 is unlikely to disappear, but in time, the disease could become endemic. It is necessary to make the pandemic something less threatening like the flu, foot-and-mouth disease or chickenpox, and return to normal life. However, new mutations in COVID-19 may require additional vaccines in the future. In preparation for such a scenario, Singapore accepts the need to develop multi-annual vaccination programs. It has planned to change the current testing strategy in Singapore. It intends not to focus on tracking and isolating contacts, but to ensure safe events, social activities and travel. One of the key elements of the strategy is social responsibility of people. Individuals will have the opportunity to test themselves if necessary, to self-isolate in case of positive tests. Instead of daily monitoring for COVID-19 infection rates, attention will be paid to severe cases. The implementation of these measures will make it possible to lift restrictions, re-launch major measures, and normalize business activities and the re-establish travel.

The sustain-and-support strategy generally aims at maintaining the current governance model. This strategy characterizes by the abandonment of strict restrictive measures while maintaining segmented and moderate restrictions. Voluntary restrictive measures, such as the use of facial masks in public places, in transport, are pronounced. The strategy focuses on the development of herd immunity. Economic activities are fully maintained, but in some cases subject to restrictions. As a result, the overall quality of life of the population is almost unchanged, the gross domestic product of the countries is growing, and the public administration institutions and establishments remain highly reliable. The most striking example of this strategy is Sweden, whose approach bases on selective and mainly voluntary restrictions. It focuses on protecting vulnerable segments of the population, such as the elderly, while keeping a large part of society and the economy open. The goal is not so much to limit community spread as to manage it in order to build herd immunity, to maintain a healthy environment. The current number of cases of COVID-19 has not completely overwhelmed the Swedish healthcare system. Population as a whole has maintained their existing access to health services that is more sustainable and is likely to maintain citizens' trust and support over time. So far, survey data suggest that most Swedes support the approach of the government.

The implementation of these strategies may relate to national liberal or expansive traditions, the peculiarities of the legal framework, the prevailing cultural value system. In studying pandemic containment strategies B.Travica acknowledges that the public and political response to the COVID-19 outbreak is very dynamic and subject to frequent changes [9]. Analyzing the experience of Europe and other regions in the pandemic management, the conclusion is that there are three key types of strategies in limiting COVID-19. Liberal strategy is with the lowest restrictive measures for natural persons and legal persons (Sweden). Most restrictive measures are of a recommendatory nature. A repressive strategy is a strategy in which a number of countries impose regulatory restrictions for which there is a specific liability for breach. In certain periods the activities of people, enterprises and institutions are subject to strict control, curfew and quarantine are possible (Lithuania, Spain, Belgium). The third strategy, conditionally, is a hybrid strategy, which can be a combined 
liberal approach with normative restrictive measures (Latvia, Estonia). The movement of people is recorded by video technologies (running digital tracking, the application "ApturiCovid" is installed), physical and social distance is common. Acceptance and implementation of appropriate strategies is undoubtedly linked to the epidemiological situation of countries, peculiarities of the legal system, cultural traditions, and technological possibilities.

Regardless of the practice of adopting and implementing strategies, legal experts and epidemiologists acknowledge that COVID-19 has not disappeared and cannot be destroyed. It has spread not only to humans in all regions of the world, but also to more than a dozen different animal species [10]. Global herd immunity, as one of the key factors in containment the pandemic, regardless of drastic or liberal strategies, is unreachable for a variety of reasons. In countries where vaccines are available a lot of people do not want to get vaccinated, for example, in Latvia, according to the results of the study "Mana Aptieka \& Apotheka Veselibas indekss", $42 \%$ of respondents do not plan to get vaccinated [11]. Among them, 20\% are completely convinced of their choice not to vaccinate, while $22 \%$ have indicated that they would rather. The results of the study show that the most common cause for non-vaccination of the population relates to the lack of confidence that the vaccine will be able to protect of the possible disease (49\%). A sufficient proportion of respondents $(44 \%)$ cite as a reason the fear that vaccination can cause side effects. At the same time, one third of respondents (29\%) do not support vaccination at all. One in ten people (12\%) believes that they have strong health and immunity, and is convinced that even COVID-19 would not have serious consequences. Thus, it can be concluded that it will not be possible to obtain herd immunity in Latvia when $70-80 \%$ of the population of the country would have been vaccinated. A strategy to encourage people to be vaccinated is of importance.

At the same time, it should also be acknowledged that many countries do not have enough vaccines at all or they are not available in the required quantities. On June 10, 2021, the Director of the World Health Organization (WHO) T.A. Ghebreyesus acknowledged that for six months since the first vaccines were administered, high-income countries have administered almost $44 \%$ of the world's doses [12]. Low-income countries have only vaccinated $0.4 \%$ of the population. The most disappointing of these statistics is that the unfavourable trend does not change over a sufficiently long time. There is no doubt that unequal vaccination threatens all countries, not only those with the fewest vaccines, which can only contribute to the further spread of the pandemic.

At present, one can also see that COVID-19 virus is modifying, with diverse origins, spreading trends, contagiousness, as well as resistance to individual vaccines, and so on. Consequently, it is logical to conclude that civilization will have to accept and live in a viruscovered world for an indefinite time. The COVID-19 response strategy needs to include new unplanned activities in line with the new trends in the spread of the pandemic. One of the most important strategic directions is informing the population about the state of COVID-19 spread, its trends and diagnostics of new modified virus types, primary preventive measures of possible infection. A major component of the pandemic prevention strategy is the vaccine as a highly mobile resource that can be used in regions with rapidly growing trends in COVID morbidity and new strains. There are currently no conclusions on whether all vaccines are equally effective and safe, especially if new strains of the virus are taken into account (Indian, Brazilian, of South Africa, etc.).

What should and could be done to significantly limit the pandemic and prevent new threats of its spread? Obviously, there is a need for qualified and responsible human resources, specialists in epidemiological services and in the healthcare system. Material and financial resources are of importance. However, a successful fight against the pandemic is not possible without a sound policy and a carefully balanced strategy. Effective epidemiological policy and constructive strategies shall base on obtaining of operational and objective 
information on the global, regional, national and selective pandemic situation. Accurate data on possible new outbreaks of the virus, possible modifications thereof, routes of transmission, and shortcomings in restrictive measures are needed. Qualified analysis of the information obtained provides opportunities for adjusting to the pandemic containment strategy and for making changes in the legal framework for the management of COVID-19. It is positive that in Latvia, on February 9, 2021, the Cabinet approved a strategy for reducing the spread of COVID-19 and maintaining public health. The aim of the strategy is to reduce rapidly the growing morbidity in Latvia. Human safety is at the heart of it. The COVID-19 long-term management strategy sets out three performance indicators. (a) In the field of health, the aim is to reduce the total number of new COVID-19 infections per 100,000 populations to 20 in 14 days. (b) In the field of economy, the plan is to ensure the growth of the gross domestic product in 2021 for at least $3.6 \%$. (c) In the field of social security, it is intended to prevent the unemployment rate from rising above $10 \%$ [13]. Vaccination, the development of an appropriate strategy and its implementation are of great importance in limiting the spread of COVID-19. Vaccination strategies, bodies providing it, coordination centres base on the national framework for healthcare. However, in the context of the vaccination process, there are processes that are transnational in nature, difficult to determine and their content, the forms of activities and the tools used are anti-social in nature. With the decline of the COVID spread the lifting of restrictive measures and the movement of people across borders, intensive travel makes it necessary to establish and apply control mechanisms. In May 2021, the European Commission reached an agreement with the European Parliament on the introduction of a digital certificate in the European Union from July 1, 2021 [14]. The EU Digital COVID Certificate will significantly facilitate the free and safe movement of citizens within the European Union during the COVID-19 pandemic. This certificate will be introduced in EU Member States. It can already be issued and used by countries and will be available in all EU Member States. The certificate will certify that the eligible person has been vaccinated, recovered from COVID-19 or has received a negative test result. European Commission President Ursula von Leyen noted that "all EU citizens have the fundamental right to free movement within the EU. The EUDigital COVID Certificate, available in paper or digital format, will make it easier for Europeans to travel - either to see and their families and loved ones, or to earn a well-deserved holiday" [15].

It should be acknowledged that in addition to vaccination processes, the lifting of movement restrictions for vaccinated persons certain socially unfavourable and illegal manifestations developed. Since the first negative digital test certificates and corresponding certificates appeared, counterfeits of the relevant documents began to spread. In the Guardian, Jamie Grierson conducting a journalistic study, published data on the increased coverage of falsified COVID vaccines and test certificates and there is an increase in the relevant services [16]. More than 1,200 vendors operating in the UK and around the world offer fake documents with negative COVID test result of $£ 25$. By November 2020, researchers discovered about 20 Darknet web sellers, which grew to 600 in January 2021 and more than 1,200 by March. This Internet network can only be accessed with certain software. Telegram encrypted messaging service platform also has several channels, some of which have more than 1,000 subscribers, offering fake negative COVID test results and forged certificates. Israeli researchers also found evidence of falsification of NHS and US Centres for Disease Control and Prevention vaccine cards, along with fake test certificates, all of which are available for sale on the Darknet web using available platforms such as WhatsApp, Telegram and Jabber.

Due to the rapid spread of negative forged certificates, the German police have set up a special team to combat these crimes [17]. Investigating these crimes police in Cologne has recorded the use of encrypted couriers, whose identity is difficult to establish. Fake certificates are offered with possible origins from vaccination centres in Weimar, Kamenz, Munich 
and Hamburg. According to the Check Point Research centre, data counterfeit vaccine passports were sold on the black market for $\$ 250$ [18]. The procedure for obtaining passports is simple: illegal passport holders send personalized data and an appropriate deposit to a specific Telegram address, and the seller then sends the appropriate certificate to the recipient's e-mail. Users of these services have no guarantee that their personal data and accounts will not be used for further illegal activities against them. Separate studies show that Darknet advertising for COVID-19 vaccines has increased by more than $300 \%$ in the last three months. It must be acknowledged that it is difficult for the public to return to the previous restrictive provisions of COVID. Logically, a negative COVID test result or a vaccination certificate becomes the golden key that will release restrictions and allow people to move and blend with more freedom. This situation makes it possible for criminals and fraudsters to exploit people who are willing to take risks by using forged documents to gain this freedom.

\section{Evaluation of the effectiveness of COVID-19 containment strategies}

It should be acknowledged that it is a bit premature to evaluate COVID-19 containment strategies at this time. COVID-19, including its new mutations, continues to spread. In this case, the strategies that are being targeted at limiting the spread of new virus strains should already be considered. However, based on the results of individual studies, insight into evaluation of these strategies can be provided. The importance of these past assessments is that it is possible to adjust and refine the appropriate COVID-19 containment strategies. Analyzing the summary, study results and various publications it must be concluded that most of the sources for diagnosing the effectiveness of COVID-19 containment measures are related to medical, pharmaceutical and epidemiological measures. The authors of the article will focus on the overall evaluation of the respective strategies without going into the above-mentioned areas.

The majority of Latvians (46\%) evaluate the actions and decision of the government to combat COVID-19 positively [19]. At the same time, however, only a slightly lower number of respondents (43\%) evaluate government actions and decisions in this area negatively. So the polarization of opinions and views can be detected. One tenth or $11 \%$ of the population does not have a specific opinion. At the same time, the actions of the government and its operational strategy were considered by many to be ineffective, ponderous and often unclear. Data from the research company "Kantar" in May show that $60 \%$ of Latvians surveyed admitted that they "lack clarity about the duration of the emergency, a transparent plan for how to get out of it and how the country will stabilize the economic downturn [20]. The results of in-depth interviews show that the population did not see the actions of the government as an important step in strengthening their security and safety. They relied more on themselves and their loved ones. Surveys generally showed that a large part of Latvian society complied with the decisions of the government on restrictions. According to the research centre's SKDS survey $80 \%$ of the population complied with the rules and restrictions [21]. Knowledge of the extent to which a restrictive strategy is acceptable to citizens is of importance. The vast majority $-70 \%$ - of respondents have found them to be appropriate. At the same time one in ten has assessed the restrictions as too strict and $15 \%$ of respondents do the opposite - they believe that the reins should have been tightened even more during the crisis. At the same time, more than half of respondents (59\%) expressed the opinion that the Latvian government could hide important information about COVID-19). Similar opinions and views were expressed on the World Health Organization. It must be acknowledged, however, that a sufficient number of people have distrust of the information provided by the public administration, 
the validity of the COVID-19 containment strategy. Appropriate institutions do not carry out full explanatory work. The Eurobarometer survey conducted at the end of May 2021 shows that $75 \%$ agree that vaccination against COVID-19 is the only way to end a pandemic [22]. In Europe as a whole more than two thirds of the population (69\%) are either already vaccinated or want to get vaccinated as soon as possible. The vast majority (79\%) plan to get vaccinated this year. The data on the extent to which citizens are satisfied with the way in which the EU has implemented its vaccination strategy are interesting (47\% satisfied, 45\% dissatisfied). The study confirms the polarization of opinions. At the same time people's perceptions of national action have been slightly more negative (46\% satisfied, $49 \%$ dissatisfied).

It must be acknowledged that, in general, a large part of society does not see strategies of the government for long-term development. At the same time, it is not possible at present to draw objective conclusions about the effectiveness of pandemic management strategies. It can be assumed that in the second half of 2021 there could be a new wave of pandemic, which would be associated with more intensive travel of people, abstention from security and safety measures (distancing, wearing masks), widespread cultural and entertainment events. Therefore, not only global and national epidemiological safety strategies are needed, but also individual strategies, adjustment of individual behavioural patterns.

\section{Conclusions}

1. In the field of containment of COVID-19 it is possible to identify different and diverse strategies, differentiated based on their coverage, the severity of the restrictive measures, as well as the pandemic development periods.

2. It is of importance to ensure that restrictive measures are proportionate to the rights and freedoms of individuals in the development and implementation of pandemic containment strategies.

3. Boston Consulting Group has a matter-of-fact constructive approach and distinguishes the following strategies: crush and contain; flatten and fight; sustain and support.

4. The experience of Europe and other regions shows that liberal, repressive and hybrid strategies are being implemented in the management of the pandemic. Acceptance and implementation of appropriate strategies relate to the epidemiological situation of countries, peculiarities of the legal system, cultural traditions, and technological possibilities.

5. It is necessary to admit that COVID-19 virus is modifying, new strains of the virus are developing, as well as their resistance to individual vaccines. The COVID-19 response strategy needs to include new unplanned activities in line with the new trends in the spread of the pandemic.

6. With the decline of the COVID spread the lifting of restrictive measures and the movement of people across borders, intensive travel makes it necessary to establish and apply control mechanisms. The digital certificate is being introduced in Europe confirming that the eligible person has been vaccinated, recovered from COVID-19 or has received a negative test result.

7. With the lifting of movement restrictions for vaccinated persons, certain socially unfavourable and illegal counterfeits of the relevant documents and the market for appropriate services, which determines a new type of proactive action for law enforcement authorities, began to spread.

8. Selection studies show that citizens have different attitudes towards the COVID-19 containment strategy of the government. Citizens do not have sufficient and convincing information about the actions of the government in managing the pandemic. The Eurobarometer surveys also show that, in general, government actions in Europe are more likely to be assessed negatively. 


\section{References}

[1] Svešvārdu vārdnīca, Rīga, Avots, 862 (2008)

[2] A. Vilks. Krimināltiesiskā politika: diskursa analize un attīstības perspektīvas. Rīga, Drukātava 67 (2013)

[3] COVID-19 Strategy Update, Available: https://www.who.int/publications/m/item/covid19-strategy-update [2020]. [Accessed: 5.05.2021]

[4] Three Paths to the Future (2020). Available: https://www.bcg.com/publications/2020/ three-paths-to-the-future-post-covid-19 (2020). [Accessed: 10.05.2021]

[5] Chang, Wen-Chen, Taiwan's Fight against COVID-19: Constitutionalism, Laws, and the Global Pandemic (2020). Available: https://verfassungsblog.de/taiwansfight-against-covid-19-constitutionalism-laws-and-the-global-pandemic/.]. [Accessed: 5.05.2021]

[6] Taiwan Centers for Disease Control. Available: https://www.mohw.gov.tw/cp-463851297-2.html. [Accessed: 12.05.2021]

[7] Singapore planning for a new normal of living with endemic COVID-19: PM Lee Hsien Loong. Available: https://ifonlysingaporeans.blogspot.com/2021/06/singaporenew-normal-covid-19-pm-lee.html. [Accesed: 15.05.2021]

[8] Singapuras amatpersonas nāk klajā ar stratēǵiju cina ar Covid-19 celā uz “jauno normālo" (2021). Pieejams: https://www.apollo.lv/7281170/singapurasamatpersonas-nak-klaja-ar-strategiju-cina-ar-covid-19-cela-uz-jauno-normalo. [Accessed: 12.05.2021]

[9] B. Travica. Containment Strategies for COVID-19 Pandemic (2020). Available:: https://ssrn.com/abstract=3604519. [Accesed: 22.04.2021]

[10] L. Brilliant, L. Danzig, K. Oppenheimer, A. Mondal, R. Bright, W. Lipkin, A Strategy for the Long Fight Against COVID-19 (2021). Available: https://www.foreignaffairs.com/articles/united-states/2021-06-08/coronavirus-strategyforever-virus 2021. [Accessed: 1.06.2021]

[11] Aptauja: 42\% Latvijas iedzīvotāju neplāno vakcinetīes pret Covid-19 (2021). Pieejams: https://skaties.lv/zinas/latvija/sabiedriba/aptauja-42-latvijas-iedzivotaju-neplanovakcineties-pret-covid-19/. [Accessed: 25.05.2021]

[12] WHO Director-General'sopeningremarksattheMemberStateInformationSessionon COVID-19 - 10 June 2021. Available: https://www.who.int/directorgeneral/speeches/detail/who-director-general-s-opening-remarks-at-the-memberstate-information-session-on-covid-19-10-june-2021. [Accessed: 20.06.2021]

[13] Stratēéija par nepieciešamo pasākumu kopumu Covid-19 infekcijas izplatības pārvaldīšanai 2021. gadam (2021). Available: https://www.mk.gov.lv/sites/mk/files/media_file/strategija-covid-19-parvaldisanai2021.pdf. [Accessed"13.05.2021]

[14] EU Digital COVID Certificate (2021). Available: https://ec.europa.eu/commission/presscorner/detail/en/IP_21_2721. [Accessed: 16.05. 2021]

[15] EU

Digital

COVID

Certificate

(2021).

Available: https://ec.europa.eu/commission/presscorner/detail/en/ip_21_2593.

[Accessed: 24.05.2021]

[16] J. Grierson, Fake Covid vaccine and test certificate market is growing, researchers say (2021). Available: https://www.theguardian.com/world/2021/may/16/fake-covidvaccine-and-test-certificate-market-is-growing-researchers-say. [Accessed: 30.06. 2021] 
[17] Coronavirus: Germany fights trade (2021). Available: https://www.bbc.com/news/world-europe-57344546). [Accessed: 30.06.2021]

[18] A passport to freedom (2021). Available: https://blog.checkpoint.com/2021/03/22/apassport-to-freedom-fake-covid-19-test-results-and-vaccination-certificates-offeredon-darknet-and-hacking-forums/. [Accesed: 28.06.2021]

[19] Aptauja: kā Latvijas iedzīvotāji vērtē pēdējos valdības lēmumus Covid-19 apkarošanai (2020). Available: https://nra.lv/latvija/327723-aptauja-ka-latvijas-iedzivotaji-vertepedejos-valdibas-lemumus-covid-19-apkarosanai.htm. [Accesed: 28.05.2021]

[20] Covid-19 Latvījā: vai esam veiksmīgākie Eiropā? (2020). Available: https://lvportals.lv/viedokli/319822-covid-19-latvija-vai-esam-veiksmigakie-eiropa2020). [Accesed: 30.05.2021]

[21] 70\% iedzīvotāju aptaujā atzīst: Covid-19 ierobeojumi apgrūtinoši, bet vajadz̄̄gi . Available: https://www.lsm.lv/raksts/zinas/latvija/70-iedzivotaju-aptauja-atzist-covid19-ierobezojumi-apgrutinosi-bet-vajadzigi.a358919. [Accessed: 22.05.2021]

[22] Attitudes on vaccination against Covid-19 (2021). Available: https://europa.eu/eurobarometer/surveys/detail/2512). [Accessed: 29.06.2021 